\title{
Ultra Sonographic Evaluation of the Pancreatic Size in Type II Egyptian Diabetic Patients
}

\author{
AZZA S. KHALAF, M.Sc.; MOHAMMED H. ABO FREIKHA, M.D.; SHERIF E. EZZAT, M.D. and \\ ABDALLAH A. AL-SAWY, M.D.
}

The Department of Internal Medicine, Faculty of Medicine, Tanta University

\begin{abstract}
Background: The pancreas is an insulin-secreting gland and is prone to varying degrees of destruction and change in patients with Diabetes Mellitus (DM). Various morphological changes including reduction in the pancreas size have been described in DM. Real time sonography can assess the gland in most of cases and it is accurate in diagnosis of pancreatic disorders.
\end{abstract}

Aim of Study: To evaluate the pancreatic size in type II Egyptian diabetic patients.

Patients and Methods: Comparative cross-sectional study was carried out on 120 subjects over a 6 month period in Tanta University Hospitals to evaluate the ultra sonographic size of the pancreas and both the duration of the disease and type of treatment in type II Egyptian diabetic patients. Group (A): 100 patients with type II diabetes mellitus. Group (B): 20 non-diabetic patients (healthy controls). We excluded patients of type I diabetes mellitus and patients with known or possible history of pancreatic diseases such as pancreatitis, cystic fibrosis, autoimmune disorders, pancreatic tumors, and chronic alcohol consumption. Complete clinical examination, routine laboratory investigations and specific investigation including. $\mathrm{HbA}_{1 \mathrm{c}}$ and Pelvi-abdominal ultrasonography were done. Sonographic measurements of the size of the pancreatic head, body, and tail of both study groups were performed.

Results: There is a significant difference between diabetic group and control group as regard to head $(\mathrm{cm})$, body $(\mathrm{cm})$ and tail $(\mathrm{cm}), p$-value $(0.001,0.001$ and 0.001$)$. There are pancreatic head, body and tail size decrease more significantly in the group on oral hypoglycemic drugs than the group receiving oral hypoglycemic drugs plus insulin $p$-value $(0.001$, $0.001,0.037)$. There is a negative significant correlation between duration and pancreatic head, body and tail size in diabetic group, $p$-value $(0.001,0.001,0.001)$.

Conclusion: From the results of the present study, we can conclude that the pancreas size of diabetic patients is significantly smaller than those of normal control group. We also concluded that in type II diabetes longer duration of illness was associated with smaller pancreas head, body and tail size. The pancreatic head, body and tail size decrease more signif-

Correspondence to: Dr. Azza S. Khalaf, The Department of Internal Medicine, Faculty of Medicine, Tanta University icantly in the group on oral hypoglycemic drugs than the group receiving oral hypoglycemic drugs plus insulin.

Key Words: Pancreas - Diabetes mellitus - Ultrasonography.

\section{Introduction}

THE pancreas is a non encapsulated, retroperitoneal organ that lies in the anterior pararenal space between the duodenal loop and splenic hilum. various types of morphological changes in the pancreas have been described in patients with Diabetes Mellitus (DM). Pathologists have demonstrated islet cell pancreatic changes in DM such as hyalinization, fibrosis, hydropic degeneration, and hyperplasia [1]. Moreover, studies in cellular composition of the pancreas in type II diabetes have demonstrated a decrease in beta cell mass [2]

Diabetes mellitus is a metabolic disorder of multiple causes characterized by chronic hyperglycemia and disorders of carbohydrate, fat, and protein metabolism. It results from defects in insulin secretion, insulin action, or a combination of these factors [3]

Diabetes can be classified in to the following general categories: Type I diabetes (due to autoimmune b-cell destruction, usually leading to absolute insulin deficiency). Type II diabetes (due to a progressive loss of beta cell insulin secretion frequently on the back ground of insulin resistance). Gestational Diabetes Mellitus (GDM) (diabetes diagnosed in the second or third trimester of pregnancy that was not clearly overt diabetes prior to gestation). Specific types of diabetes due to other causes, e.g., monogenic diabetes syndromes (such as neonatal diabetes and Maturity-Onset Diabetes of the Young [MODY]), diseases of the exocrine pancreas (such as cystic fibrosis and pancreatitis), and drug-or chemical-induced diabetes (such as 
with glucocorticoid use, in the treatment of HIV, or after organ transplantation) [3].

Abdominal ultrasound is used in the hospital, Radiology Department and Emergency Department, as well as in physician offices for a number of clinical applications. It has a great advantage over plain radiography in that it does not predispose tissues to the hazard of ionizing radiation. Ultrasound is also generally far better than plain radiography at distinguishing the subtle variation of soft tissue structures [4].

\section{Patients and Methods}

This comparative cross-sectional study was carried out on 120 subjects in Tanta University Hospitals in the period from November 2017 to June 2018 to evaluate the ultra sonographic size of the pancreas and both the duration of the disease and type of treatment in type II Egyptian diabetic patients. All participant provided informed written consent and the study was approved by Tanta Faculty of Medicine Ethical Committee.

The following groups were included in the present study:

1- Group A: 100 patients with type II diabetes mellitus. A diagnosis of diabetes was established if a patient was already on oral hypoglycemic drugs or insulin, if fasting blood glucose was $\geq 126 \mathrm{mg} / \mathrm{dl}$ on 2 consecutive days, if 2 -hours post prandial blood glucose $\geq 200 \mathrm{mg} / \mathrm{dl}$ or HbA1c levels were $\geq 6.5 \%$.

2- Group B: 20 non-diabetic patients (healthy controls). All subjects were submitted to careful history taking, thorough clinical examination, routine laboratory and specific laboratory investigation $\left(\mathrm{HbA}_{1_{\mathrm{c}}}\right)$ and pelvi-abdominal ultrasonography.

\section{Inclusion criteria:}

Patients with type II diabetes mellitus.

\section{Exclusion criteria:}

Patients of type I diabetes mellitus. Patients with known or possible history of pancreatic diseases such as pancreatitis, cystic fibrosis, autoimmune disorders, pancreatic tumors, and chronic alcohol consumption.

\section{Statistical analysis:}

Statistical presentation and analysis of the present study was conducted, using the mean, standard deviation and chi-square test by SPSS V.22.

\section{Results}

There is no significant difference between diabetic group and control group as regard to age (years), HB (g/dl), bilirubin (mg/dl), ALT (u/l), AST $(\mathrm{u} / \mathrm{l})$, S. albumin $(\mathrm{g} / \mathrm{dl})$ and urea $(\mathrm{mg} / \mathrm{dl}), p$ value $(0.053,0.547,0.173,0.610,0.610,0.701$ and 0.053$)$. And there is a significant difference between diabetic group and control group as regard to creatinin $(\mathrm{mg} / \mathrm{dl}), \operatorname{RBS}(\mathrm{mg} / \mathrm{dl}), \operatorname{HbA}_{1 \mathrm{C}}(\%)$, head $(\mathrm{cm})$, body $(\mathrm{cm})$ and tail $(\mathrm{cm})($ Table 1$)$.

Table (1): Comparison between diabetic group and control group as regard to age, Hemoglobin (HB), bilirubin, ALT, AST, S. albumin, urea, creatinin, Random Blood Sugar (RBS), HbA 1C, the size of head, body and tail of pancreas.

\begin{tabular}{|c|c|c|c|c|}
\hline & Range & Mean \pm SD & $t$-test & $p$-value \\
\hline $\begin{array}{c}\text { Age (years) } \\
\text { Diabetes } \\
\text { Control }\end{array}$ & $\begin{array}{l}40-65 \\
40-58\end{array}$ & $\begin{array}{l}54.75 \pm 6.69 \\
51.65 \pm 5.29\end{array}$ & 3.811 & 0.053 \\
\hline $\begin{array}{c}H B(g / d l): \\
\text { Diabetes } \\
\text { Control }\end{array}$ & $\begin{array}{l}9-12.8 \\
9-12.5\end{array}$ & $\begin{array}{l}10.67 \pm 1.04 \\
10.82 \pm 0.84\end{array}$ & 0.364 & 0.547 \\
\hline $\begin{array}{c}\text { Bilirubin }(m \\
\text { Diabetes } \\
\text { Control }\end{array}$ & $\begin{array}{l}0.7-1 \\
0.7-1\end{array}$ & $\begin{array}{l}0.96 \pm 0.08 \\
0.94 \pm_{0.10}\end{array}$ & 1.884 & 0.173 \\
\hline $\begin{array}{c}A L T(u / l): \\
\text { Diabetes } \\
\text { Control }\end{array}$ & $\begin{array}{l}11-35 \\
11-35\end{array}$ & $\begin{array}{l}19.72 \pm 6.09 \\
18.95 \pm 6.48\end{array}$ & 0.261 & 0.610 \\
\hline $\begin{array}{c}A S T(u / l): \\
\text { Diabetes } \\
\text { Control }\end{array}$ & $\begin{array}{l}11-35 \\
11-35\end{array}$ & $\begin{array}{l}19.72 \pm 6.09 \\
18.95 \pm 6.48\end{array}$ & 0.261 & 0.610 \\
\hline $\begin{array}{l}\text { S. Albumin } \\
\text { Diabetes } \\
\text { Control }\end{array}$ & $\begin{array}{l}3-5.5 \\
3-5.5\end{array}$ & $\begin{array}{l}4.16 \pm 0.73 \\
4.23 \pm 0.72\end{array}$ & 0.149 & 0.701 \\
\hline $\begin{array}{c}\text { Urea }(\mathrm{mg} / \mathrm{d} \\
\text { Diabetes } \\
\text { Control }\end{array}$ & $\begin{array}{l}10-35 \\
13-35\end{array}$ & $\begin{array}{r}18.76 \pm 5.52 \\
21.45 \pm 6.16\end{array}$ & 3.808 & 0.053 \\
\hline $\begin{array}{c}\text { Creatinin } \\
\text { Diabetes } \\
\text { Control }\end{array}$ & $\begin{array}{l}0.8-1.6 \\
0.8-1.1\end{array}$ & $\begin{array}{l}1.15 \pm 0.21 \\
0.94 \pm 0.10\end{array}$ & 18.281 & $0.001 *$ \\
\hline $\begin{array}{c}R B S(m g / d l) \\
\text { Diabetes } \\
\text { Control }\end{array}$ & $\begin{array}{l}180-330 \\
80-120\end{array}$ & $\begin{array}{c}234.98 \pm 34.16 \\
100.70 \pm 9.80\end{array}$ & 302.239 & $0.001 *$ \\
\hline $\begin{array}{c}H b A_{l_{C}}(\%) \\
\text { Diabetes } \\
\text { Control }\end{array}$ & $\begin{array}{l}6.3-8.2 \\
4.5-6\end{array}$ & $\begin{array}{l}7.02 \pm 0.42 \\
5.31 \pm 0.44\end{array}$ & 271.424 & $0.001 *$ \\
\hline $\begin{array}{c}\text { Head }(\mathrm{cm}): \\
\text { Diabetes } \\
\text { Control }\end{array}$ & $\begin{array}{l}1.52-2.65 \\
2.1-2.5\end{array}$ & $\begin{array}{l}2.00 \pm 0.19 \\
2.29 \pm 0.15\end{array}$ & 41.984 & $0.001 *$ \\
\hline $\begin{array}{c}\text { Body }(\mathrm{cm}): \\
\text { Diabetes } \\
\text { Control }\end{array}$ & $\begin{array}{l}0.8-1.25 \\
1-1.6\end{array}$ & $\begin{array}{l}1.05 \pm 0.13 \\
1.39 \pm 0.18\end{array}$ & 101.787 & $0.001^{*}$ \\
\hline $\begin{array}{l}\text { Tail }(\mathrm{cm}) \text { : } \\
\text { Diabetes } \\
\text { Control }\end{array}$ & $\begin{array}{l}0.74-1.13 \\
1.1-1.5\end{array}$ & $\begin{array}{c}0.94 \pm 0.09 \\
1.33 \pm 0.12\end{array}$ & 276.060 & $0.001 *$ \\
\hline
\end{tabular}


There is a significant decrease in head, body and tail size in diabetic group more than the control group. There is no significant correlations between diabetic group and control group as regard to sex (Table 2).

Table (2): Comparison between diabetic group and control group as regard to sex.

\begin{tabular}{clll}
\hline Sex & Diabetic & Control & Total \\
\hline Male: & & & \\
$\mathrm{N}$ & 41 & 10 & 51 \\
$\%$ & $41.0 \%$ & $50.0 \%$ & $42.5 \%$ \\
Female: & & & \\
$\mathrm{N}$ & 59 & 10 & 69 \\
$\%$ & $59.0 \%$ & $50.0 \%$ & $57.5 \%$ \\
Total: & & & \\
$\mathrm{N}$ & 100 & 20 & 120 \\
$\%$ & $100.0 \%$ & $100.0 \%$ & $100.0 \%$ \\
Chi-square: & & & \\
$\chi^{2}$ & & 0.552 & \\
p-value & & 0.457 & \\
\hline
\end{tabular}

There are pancreatic head, body and tail size decrease more significantly in the group on oral hypoglycemic drugs than the group receiving oral hypoglycemic drugs plus insulin (Table 3 ).

Table (3): Comparison between oral hypoglycemic drugs and oral hypoglycemic drugs + insulin treatment in diabetic group as regard to pancreatic head, body and tail size.

\begin{tabular}{lllll}
\hline & Range & Mean \pm SD & $t$-test & $p$-value \\
\hline $\begin{array}{l}\text { Head }(\mathrm{cm}): \\
\quad \text { Oral }\end{array}$ & $1.52-2.18$ & $1.95 \pm 0.15$ & 58.895 & $0.001^{*}$ \\
$\quad$ Oral + Insulin & $2.19-2.65$ & $2.28 \pm 0.12$ & & \\
Body $(\mathrm{cm}):$ & & & & \\
$\quad$ Oral & $0.8-1.25$ & $1.03 \pm 0.12$ & 17.883 & $0.001^{*}$ \\
$\quad$ Oral + Insulin & $0.94-1.25$ & $1.17 \pm 0.07$ & & \\
Tail $(\mathrm{cm}):$ & & & & \\
$\quad$ Oral & $0.74-1.13$ & $0.94 \pm 0.09$ & 4.454 & $0.037^{*}$ \\
$\quad$ Oral + Insulin & $0.89-1.1$ & $0.99 \pm 0.05$ & & \\
\hline
\end{tabular}

There is a negative significant correlation between duration and pancreatic head, body and tail size in diabetic group (Table 4) and Figs. (1-3).

Table (4): Correlation between duration with pancreatic head, body and tail size in diabetic group.

\begin{tabular}{lcc}
\hline & \multicolumn{2}{c}{ Duration } \\
\cline { 2 - 3 } & $r$ & $p$ \\
\hline Head & -0.583 & $0.001 *$ \\
Body & -0.432 & $0.001 *$ \\
Tail & -0.692 & $0.001 *$ \\
\hline
\end{tabular}

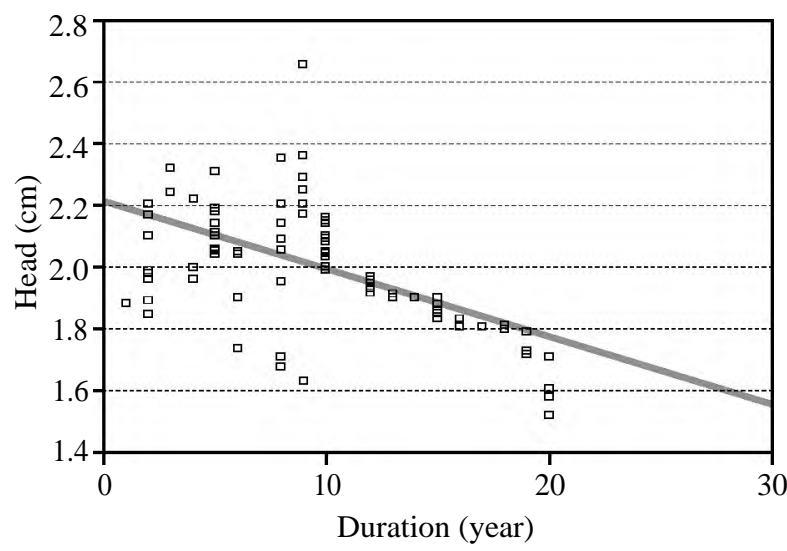

Fig. (1): Correlation between duration with pancreatic head size in diabetic group.

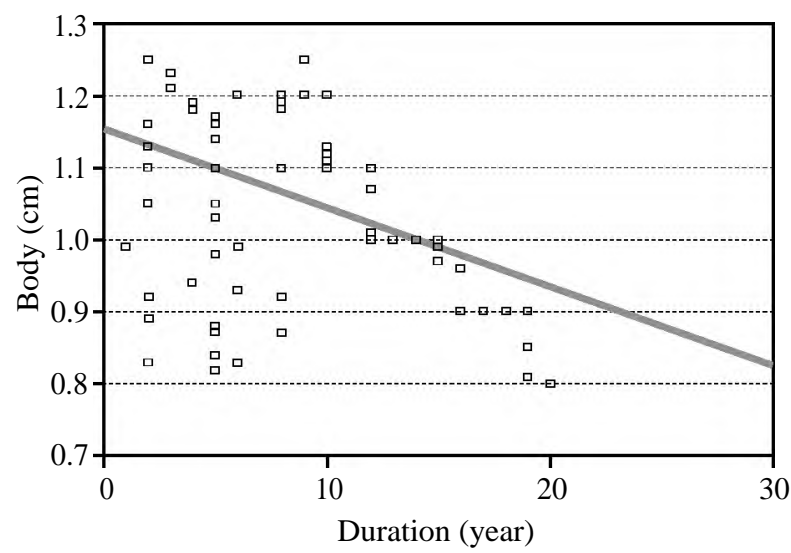

Fig. (2): Correlation between duration with pancreatic body size in diabetic group.

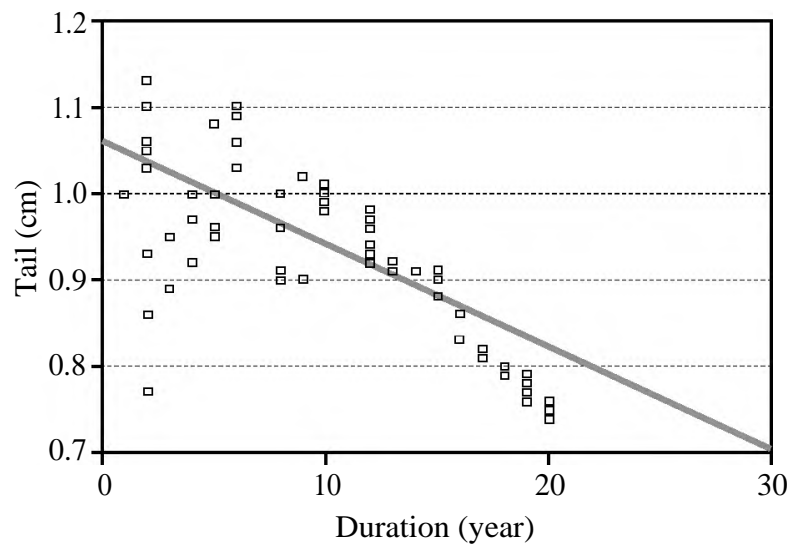

Fig. (3): Correlation between duration with pancreatic tail size in diabetic group.

\section{Discussion}

In our study, there is a significant difference between diabetic group and control group as regard to head $(\mathrm{cm})$, body $(\mathrm{cm})$ and tail $(\mathrm{cm})$. There are pancreatic head, body and tail size decrease more significantly in the group on oral hypoglycemic drugs than the group receiving oral hypoglycemic 
drugs plus insulin. There is a negative significant correlation between duration and pancreatic head, body and tail size in diabetic group.

Agabi and Akhigbe, [5] reported that the pancreas Anteroposterior (AP) dimensions of diabetics are significantly smaller than those of normal control group. Longer duration of illness of DM was also associated with smaller pancreatic body and tail dimensions, while pancreas head dimension was not significantly affected by the duration of illness and that study was in agreement with our study.

In the study of Goda et al., [6], diameters of pancreas were greatly lower in type I DM than in type II and both were significantly lower than in the normal group and this was in agreement with the results of our study.

Regnell et al., [7], demonstrated that pancreas of the type 1 diabetic patients was significantly smaller than the pancreas of the nondiabetic subjects, whereas the pancreas of the type II diabetics was less reduced in size compared to the type 1 but still smaller than the pancreas of the control group and this was in agreement with the results of our study.

Basiratnia et al., [8] also noted a smaller pancreatic size in diabetics with a significant difference in the pancreas head and body dimensions in the three groups; types I, II diabetes and controls. The results showed that the mean diameters of head and body of pancreas in patients with types I and II DM were significantly different from healthy controls and this was in agreement with the results of our study.

Skar et al., [9] have shown that smaller pancreas size in diabetes may be due to atrophy of the pancreas exocrine tissue, as well as a decrease in the beta cell mass and this was in agreement with the results of our study.

Khojaly et al., [11], a linear correlation was done in order to assess these relationship between the pancreatic size (head, body and tail) and duration of diabetes mellitus in order to investigate the effect of these duration on the size of pancreas and the results show significant strong inverse relationship between the pancreatic size (head, body and tail) and the duration of diabetes mellitus and this was in agreement with the results of our study.

Garcia et al., [11], noted that Individuals with $\mathrm{T}_{1} \mathrm{DM}$ and $\mathrm{T}_{2} \mathrm{DM}$ have reduced pancreas size in comparison with control subjects and this also was in agreement with the results of our study.

Virostko et al., [12], have suggested progressively smaller pancreatic size with increased duration of DM (decline rate of $0.013 \mathrm{~cm}^{3} / \mathrm{kg}$ per year) and this was in agreement with the result of our study.

Saisho et al., [13], Yagihashi, [14], reported that there was significantly reduced size of pancreas in type II diabetes as well as an irregular out line of the pancreatic border and this was in agreement with the result of our study.

Yagihashi, [14] reported that the major factors for altered size and structure of the pancreas in diabetic patients may be due: (I) Lack of insulin action on the exocrine pancreas resulting in tissue atrophy, as insulin is a potent growth factor for the exocrine pancreas (disruption of endocrine and exocrine relationship); (II) There also emerges a possibility that immune or inflammation mediated damage might involve both endocrine and exocrine tissues in diabetic patients, resulting in significant parenchymal atrophy. (III) Excessive fat infiltration might also result in replacement of acinar tissues in type II diabetic patients, with resultant loss of pancreas volume.

\section{Conclusion:}

- The pancreas size of diabetics is significantly smaller than those of normal control group.

- In type II diabetes, longer duration of illness was associated with smaller pancreas head, body and tail size.

- The pancreatic head, body and tail size decrease more significantly in the group on oral hypoglycemic drugs than the group receiving oral hypoglycemic drugs plus insulin.

\section{Recommendations:}

- It is recommended that pancreas size measurements should be included as screening parameters for suspected cases of DM while fasting blood sugar test should be requested for incidental cases of reduced pancreas dimensions noted on sonography.

- It is recommended also that the size of pancreas may be taken as a possible predictor factor to shift to insulin faraway in controlling diabetes.

\section{References}

1- ROGER S. and TOM W.: Clinical Sonography, a Practical Guide. 4th ed. New York. Lippincott Williams and Wilkins, p. 54-62, 2007. 
2- ROY T.: The role of the islet cell function in the onset and progression of type 2 diabetes. US Endocr Dis., 22: 366-71, 2006

3- American Diabetes Association. 2. Classification and Diagnosis of Diabetes: Standards of Medical Care in Diabetes 2018. Diabetes Care, 41 (Suppl 1): S13-S27, 2018.

4- LOUISE S.: The role of abdominal ultrasound in the diagnosis, staging and management of liver diseases. J. R. Soc. Med., 98: 17-27, 2005.

5- AGABI J.O. and AKHIGBE A.O.: Comparative sonographic evaluation of the anteroposterior dimensions of the pancreas in diabetics and nondiabetics. Niger. J. Clin. Pract., 19: 175-81, 2016.

6- GODA K., SASAKI E., NAGATA K., FUKAI M., OHSAWA N. and HAHAFUSA T.: Pancreatic volume in type 1 and type 2 diabetes mellitus. Acta. Diabetol., 38 (3): 145-9, 2001.

7- REGNELL S.E., PETERSON P., TRINH L., BROBERG P., LEANDER P., LERNMARK A., MÅNSSON S. and ELDING LARSSON H.: Pancreas volume and fat fraction in children with Type 1 diabetes. Diabet. Med., Oct., 33 (10): 1374-9, 2016

8- BASIRATNIA R., HEKMATNIA A. and KOLAHRIZ M.R.: Ultrasonographic alterations of pancreas in diabetic patients. J.R.M.S., 12 (1): 21-3, 2007.
9- SKAR M., VILLUMSEN A.B., CHRISTENSEN D.L., PETERSEN J.H., DEEPA M., ANJANA R.M., et al.: Increased risk of type 2 diabetes with ascending social class in urban South Indians is explained by obesity: The Chennai urban rural epidemiology study (CURES-116). Indian J. Endocrinol. Metab., 17: 1084-9, 2013.

10- KHOJALY S.N., ZIDAN M.M., ALI W.M. and HAMID A.S.: Assessment of pancreatic size in diabetic patients using ultrasonography. International Journal of Science and Research (IJSR), 5 (12): 1-2, 2016.

11- GARCIA T. S., RECH T.H. and LEITÃO C.B.: Pancreatic size and fat content in diabetes: A systematic review and meta-analysis of imaging studies. POLS ONE, 12 (7): $1-$ 15, 2017.

12- VIROSTKO J., HILMES M., EITEL K., MOORE D.J. and POWERS A.C.: Use of the Electronic Medical Record to Assess Pancreas Size in Type 1 Diabetes. PloS one, 11 (7): $\mathrm{e} 0158825,2016$

13- SAISHO Y., BUTLER A.E., MEIER J.J., et al.: Pancreas volumes in humans from birth to age one hundred taking into account sex, obesity, and presence of type 2 diabetes. Clin. Anat., 20: 933-42, 2007.

14- YAGIHASHI S.: Diabetes and pancreas size, does it matter? J. Diabetes Investig., 8 (4): 413-5, 2017.

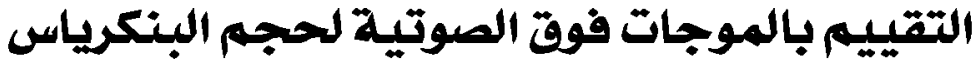

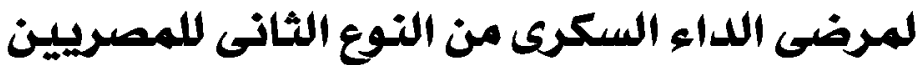

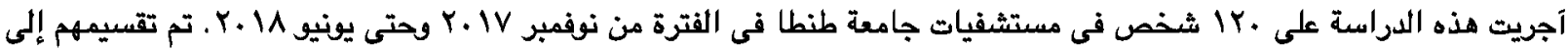

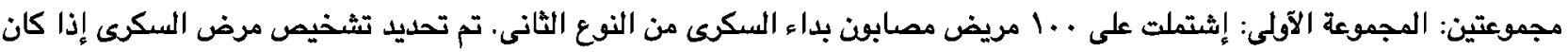

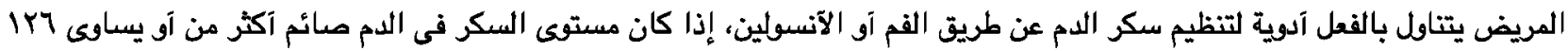

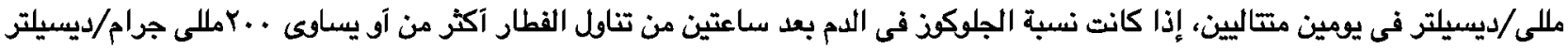

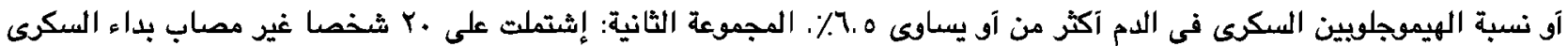

(المجموعة الضابطة).

وقد خلصت الدراسة إلى آنه حجم البنكرياس لمرضى السكر آصغر بكثير من حجم البنكرياس فى المجموعة الضابطة، وفى النوع الثانى (رئى

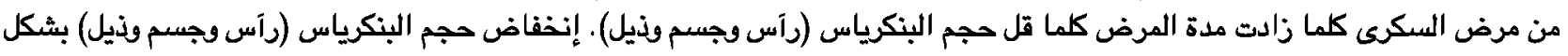

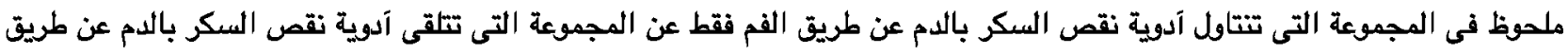
الفم والآنسولين.

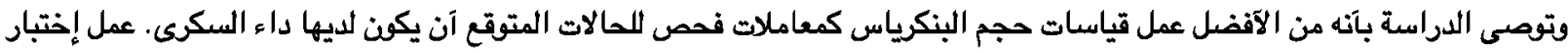

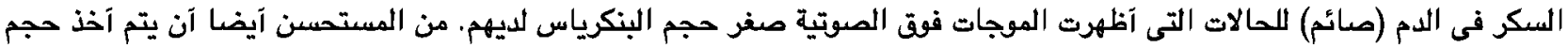
البنكرياس كعامل تنبؤ ممكن للتحول إلى الآنسولين. 